\author{
Mariusz Malinowski \\ Poznań University of Life Sciences \\ e-mail: mariusz.malinowski@up.poznan.pl \\ ORCID: 0000-0002-9602-6672
}

\title{
ENTREPREURSHIP VS. STANDARD OF LIVING OF THE POPULATION IN WESTERN POLAND: A SPATIAL ANALYSIS
}

\author{
DOI: $10.15611 / \mathrm{pn} .2020 .4 .10$ \\ JEL Classification: C21, I31, R15 \\ (C) 2020 Mariusz Malinowski
}

This is an open access article distributed under the Creative Commons Attribution-NonCommercial-NoDerivs license (http://creativecommons.org/licenses/by-nc-nd/3.0/)

Quote as: Malinowski, M. (2020). Entrepreneurship vs. standard of living of the population in western Poland: a spatial analysis. Prace Naukowe Uniwersytetu Ekonomicznego we Wrocławiu, 64(4).

\begin{abstract}
The author of this paper intends to present the relationships between the level of entrepreneurship and the population's standard of living. This study covered 112 districts in the Dolnośląskie, Lubuskie, Opolskie, Wielkopolskie and Zachodniopomorskie voivodeships. Entrepreneurship levels and standard of living were assessed with the use of TOPSIS. The variables were selected based on relevance, statistical and formal criteria (mainly including completeness and availability of 2018 data for the objects covered by the study). As shown by this study, moderate correlation exists between the phenomena considered. The results of spatial regression analysis provide grounds for concluding that a $1 \%$ increase in the synthetic indicator of entrepreneurship results, ceteris paribus, in a $0.31 \%$ increase in the synthetic indicator of standard of living at district level.
\end{abstract}

Keywords: standard of living, linear ordering, spatial regression.

\section{Introduction}

The strategic importance of entrepreneurship as a driver of economic development at local government level is indisputable (including: through job creation, inflow of labour force, and the increase in the population's income). The definitions of entrepreneurship usually refer to a specific attitude, behaviour or process focused on seizing the opportunities offered by the market. This is reflected in the creation of new economic operators. The dynamic development of entrepreneurship in Poland 
took place as a result of the economic transformation in the late 1990s. Nowadays, a significant number of people decide to start their own business. Various factors prompt this decision, including the willingness to become independent, testing one's abilities, a desire to increase earnings or gain the respect of others. Despite these unquestionable benefits, entrepreneurship carries an inherent risk. The GUS data shows that in 2017 only about $66 \%$ of non-financial enterprises survived their first year in business (Kotowski and Pięta, 2018).

The development of entrepreneurship at regional level drives changes that are not only economic but also social and cultural in nature, and often go beyond conventional administrative borders. Therefore it is worth asking: does the level of entrepreneurship in one area affect the level of this phenomenon in another (neighbouring one)? Does the standard of living in one spatial unit determine the standard of living of the residents in neighbouring units? Are there spatial relations between the standard of living and entrepreneurship?

While researchers pay particular attention to factors that stimulate improvements in the standard of living and promote entrepreneurship, little emphasis is placed on the spatial interactions between them. This is all the more important since in the context of entrepreneurial attitudes the essence of many decision-based problems is the territorial distribution of, or relationships between, objects located across the territory. The author did not intend to seek perfect definitions of 'standard of living' and 'entrepreneurship'. This paper avoids discussing the information capacity of these concepts. Instead, it focuses on quantifying them and examining the spatial relationships between them using the classic TOPSIS method. An analysis of spatial autocorrelation was carried out to determine the strength of spatial relationships between districts in terms of standards of living and entrepreneurship levels. The next step was the spatial regression analysis. The author relied on 2018 data from the Local Data Bank of the Central Statistical Office. The study covered 112 districts located in two territorial units for statistics (NUTS 1), i.e. the south-western macro-region (the Dolnośląskie and Opolskie voivodeships) and the north-western macro-region (the Lubuskie, Wielkopolskie and Zachodniopomorskie voivodeships).

\section{The essence of standard of living and entrepreneurship}

As a multifaceted category, entrepreneurship has not yet been clearly defined.

According to Klasik (2006, p. 11) entrepreneurship is "an attribute of operation and undertaking business ventures as well as the creation and development of enterprises and entrepreneurial environments in the region". Sudoł (2006, p. 26) understands entrepreneurship as a "readiness and ability to take and solve new problems in a creative and innovative way, while being aware of the risks involved, the ability to take advantage of emerging opportunities as well as flexible adaptation to changing conditions". 
The "Global Entrepreneurship Monitor Polska 2018" report considers entrepreneurship to be "any attempt to establish a new company or a new undertaking (such as self-employment, new business organization, or expansion of an existing organization) made by an individual, a team or an existing organization" (PARP, 2017). As defined by the Quality Assurance Agency for Higher Education, entrepreneurship means the application of one's skills specifically to create and develop organizations in order to identify and build on opportunities (Bellingham, 2012).

All definitions of entrepreneurship found in the literature can be grouped into three categories which consider it to be (Piecuch, 2010):

- a specific attitude expressed by active efforts made to improve the existing world,

- a specific kind of human activity,

- a process aimed at making use of an innovative idea in the existing conditions.

Entrepreneurship is dependent on many factors. Considering the topic at hand Kuciński (1997) presents an interesting distinction of factors stimulating the development of entrepreneurship in the region. The factors are as follows: morphological factors (related to the physical and geographical features of a given region), demographic factors, economic factors (being a derivative of the region's trade resources, labour force), organizational factors (reflecting the quality and stability of authorities), structural factors (reflecting the degree of development of location systems of the economy), and interactive factors (reflecting the system of external links of the region). It is implied that a bidirectional relationship between the phenomena analyzed may occur.

No single, widely accepted definition of 'standard of living' has been developed yet. In 1954, a UN expert committee defined standard of living as "the overall actual living conditions of humans and the degree to which their physical and cultural needs are met through a flow of goods and services, whether paid or derived from social funds" (cf. Zeliaś, 2004). That definition became the basis for many other ones formulated later on. Bywalec and Rudnicki define standard of living as the degree of satisfying the needs arising from the consumption of both tangible and intangible goods made by man (Bywalec and Rudnicki, 1992). A fairly broad definition of the standard of living is proposed by Berbeka, according to whom " standard of living is the state and availability of goods and services as well as the conditions by which the individual (the community) can satisfy their material and spiritual needs and the scope of use" (Berbeka, 2006, p. 13). According to Hansen and Grubb (2002), it means utility or happiness derived from consumption (defined as a good, activity or status which individuals can attain). In the nomenclature used by One Global Economy, standards of living are primarily determined by three categories (Mourad et al. 2014): income; education; health (including the availability of a healthcare system).

Undoubtedly the very fact of having a permanent job (or the lack of it) affects the level of life satisfaction. According to Mularska-Kucharek (2016), people who engage in an economic activity, who are motivated to pursue their goals, demonstrate 
creativity and optimism and are capable of taking risks (i.e. entrepreneurial people) are better positioned to achieve more than other people. Job loss, especially in the long run, can contribute to many negative phenomena, both of an individual nature (e.g. depreciation of human capital, alienation, degradation of mental health) and social (e.g. increase in state expenditure on maintaining the unemployed), affecting the standard of living of local and regional residents.

People at low levels of entrepreneurship are much less satisfied with their lives. In turn, the study by Szczygieł and Piecuch (2016) suggests that:

- entrepreneurs are relatively wealthier than other socioeconomic groups (including temporary employees, farmers, pensioners);

- households of entrepreneurs report the highest levels of income (which they find to be useful).

It is unquestionable that the sole fact of having a job has an impact on how much an individual is satisfied with his/her life. According to (Kotowska et al., 2010), unemployment (an aspect strongly related to entrepreneurship) has the greatest adverse effect on life satisfaction. Even people who claim to struggle hard for a sound work-life balance are less dissatisfied with their lives than unemployed persons.

The growth of the self-employed group contributes to changes in the socioeconomic structure, redefines the way people operate and, as a consequence, determines their standard of living. This takes place in different ways, including (cf. Karwowski 2003): initiating new kinds of activity; creating jobs; increasing the population's income; and making that part of the population shift to a new consumption model.

Entities conducting economic activity (as a result of undertaking business ventures) are the main animators of local and regional development (followed by local government authorities and non-governmental organizations). Their unique role stems not only from the creation of jobs and stimulating economic growth, but they also play an important role in generating income in the budgets of local government units, which can later be allocated to local (regional) investments that contribute to satisfying the needs of local people and thus affecting their living standards (cf. Szot-Gabryś, 2008, p. 39).

It is worth mentioning the survey conducted by Kalinowski (2015), aimed at showing the relationship between standard of living and the income uncertainty of the rural population. One of the main target groups were the self-employed. The author recognized, among others, the material situation of households with uncertain incomes and its changes (including, income situation, assessment of their own material situation, meeting material and non-material needs as well as living standards in the broad sense). On the other hand, Majkut (2011) on the basis of surveys (focusing on trends regarding the attitudes of Wrocław residents towards the phenomenon of local entrepreneurship) and secondary data from the Central Statistical Office (GUS), conducted analyses of the impact of entrepreneurship on the quality of life of Wrocław residents. The research results indicate that the 
most important features necessary to set up one's own business are: persistence in pursuing one's goal and having no fear of taking risk. The taxonomic methods used by Janusz (2014) in this study to measure the standard of living were utilized to analyse the spatial diversity of living standards at county ('powiat') level in the Warmian-Masurian Voivodeship (based on the Hellwig method). Liang, Changdi and Liming (2017) used the TOPSIS method for sorting the major cities of Guizhou province according to the standard of living of residents.

Despite numerous analyses, both the quantification of standard of living and the identification of factors contributing to the higher level of the analysed phenomenon remains a problem that is not fully solved. This applies to both the selection of diagnostic variables, methods used to measure this phenomenon, as well as methods for identifying relations between the analysed categories. Some researchers attach particular importance to factors stimulating this element of the socio-economic system, but the issues of spatial interactions between the considered categories are stressed to a relatively low degree. This is important because in the context of entrepreneurial behaviour, many decision-making problems relate to spatial distribution or relations between elements of this space.

\section{Methodology}

Despite numerous analyses, the measurement of entrepreneurship levels is a problem that has not yet been comprehensively solved. In accordance with the Global Entrepreneurship Monitor, entrepreneurship is considered in a behavioural rather than institutional context, and includes both entrepreneurial behaviour resulting in the registration of new undertakings, and that manifested by the existing organizations (Tarnawa et al., 2017). To measure entrepreneurship at regional level, the Polish Agency for Enterprise Development uses such variables as (Tarnawa and Zadura-Lichota, 2015): active enterprises per 1000 population; revenue per enterprise; cost-to-revenue ratio; average remuneration; and capital expenditure per enterprise. The whole set of indicators used in measuring this economic category can be divided into two groups (Świętek, 2018):

- the entrepreneurial spirit (indicators related to initiatives that promote engaging in an economic activity),

- the outcomes of entrepreneurship (including entrepreneurs per 1000 working-age population; size structure).

In turn, the measurement of standard of living relies on both subjective and objective metrics. The purpose of objective metrics (expressed as a value or in natural units) is to determine the level of phenomena or processes taking place outside individuals themselves, whereas subjective metrics describe the way people feel (Kwasek, 2002).

Based on the BDL CSO data from 2018, ten variables were used to illustrate the level of entrepreneurship in counties of West Poland: P1: operators entered to the 
REGON register per 1000 population; P2: operators recently entered to the REGON register per 1000 population; P3: operators removed from the REGON register per 1000 population; P4: ratio of operators removed to the total number of operators entered to the REGON register; $\mathrm{P} 5$ : natural persons conducting business activities per 100 working-age population; P6: foundations, associations and social organizations per 1000 population; P7: recently registered foundations, associations and social organizations per 1000 population; P8: commercial companies per 1000 population; P9: ratio of recently registered operators active in the creative sector to the total number of recently registered operators; P10: capital expenditure in enterprises per person.

When analysing the above set of variables, it should be borne in mind that on the one hand they are commonly used in this type of research (e.g. Tarnawa, Zadura-Lichota, 2015), but the weakness of some of them (e.g. P1 and P2) is that they do not take into account the fact that in Polish conditions, self-employment is not an expression of entrepreneurial activities, but the effect of employers' expectations.

Next, 28 variables in 7 thematic groups were proposed to assess their standard of living (cf. Słaby, 2007; Zeliaś, 2004):

1) labour market: $X 1$ : unemployment rate; $X 2$ : number of employed per 1000 population; X3: ratio of gross remuneration to the national average figure; X4: job opportunities per unemployed person; X5: employed in hazardous work conditions per 1000 employed;

2) healthcare: X6: population served by 1 pharmacy; X7: doctors per 10,000 population; X8: dentists per 10000 population; X9: hospital beds per 10,000 population; X10: population growth rate per 1000 population;

3) environment: X11: industrial and municipal waste water as a percentage of waste water which requires treatment; X12: emission of gaseous pollutants by particularly noxious plants in tons per $\mathrm{km}^{2}$; X13: share of population served by treatment plants in the total population;

4) transport: X14: cars registered per 1000 population; X15: taxicabs per 1000 population; X16: hard surfaced district roads per $100 \mathrm{~km}^{2}$;

5) housing conditions: X17: share of dwellings equipped with central heating; $\mathrm{X} 18$ : usable floor area per person; X19: share of dwellings equipped with a bathroom; X20: share of dwellings served by gas networks; X21: share of people served by a sewerage network;

6) culture: X22: library members per 1000 population; X23: cinema seats per 1000 population; X24: beds in collective living quarters per 1000 population; $\mathrm{X} 25$ : museums per 1000 population;

7) education: X26: number of kindergarten pupils per 1000 children; X27: net enrolment rate for primary schools; X28: net enrolment rate for junior secondary schools.

The classic TOPSIS method was used to linearly order the districts by standard of living and by entrepreneurship level. According to this method, the synthetic 
indicator is created based on the Euclidean distance both from the positive ideal solution (pattern) and from the negative ideal solution (anti-pattern). The smaller the distance from the positive ideal solution (and the greater is the distance from the negative ideal solution), the higher the value of the synthetic variable (for a broader description, see: Hwang and Yoon, 1981). The steps of building the taxonomic index are as follows:

1. Creating a normalized decision matrix.

2. In the case of weighted variables, the weight matrix and following this the weighted normalized decision matrix need to be created.

3. For the normalized features, the coordinates of the positive ideal $\left(\mathrm{A}^{+}\right)$and the negative ideal $\left(\mathrm{A}^{-}\right)$solution are determined:

$$
\begin{aligned}
& A^{+}=\left(\max _{i}\left(v_{i 1}\right), \max _{i}\left(v_{i 2}\right), \ldots, \max _{i}\left(v_{i N}\right)\right)=\left(v_{1}^{+}, v_{2}^{+}, \ldots, v_{N}^{+}\right), \\
& A^{-}=\left(\min _{i}\left(v_{i 1}\right), \min _{i}\left(v_{i 2}\right), \ldots, \min _{i}\left(v_{i N}\right)\right)=\left(v_{1}^{-}, v_{2}^{-}, \ldots, v_{N}^{-}\right),
\end{aligned}
$$

4. Determining the Euclidean distance of each object from the positive ideal solution and the negative ideal solution:

$$
s_{i}^{+}=\sqrt{\sum_{j=1}^{N}\left(v_{i j}-v_{j}^{+}\right)^{2}} .
$$

5. Calculating the value of the synthetic feature: $C_{i}=\frac{s_{i}^{-}}{s_{i}^{+}+s_{i}^{-}}$, with $0 \leq C_{i} \leq 1$.

A correlation analysis was carried out to determine the strength and direction of relationships between the standard of living and entrepreneurship levels. The Spearman rank correlation coefficient was used in order to eliminate the negative impact of outliers, if any, on the results of the correlation analysis.

The analysis of both the standard of living and the levels of entrepreneurship based on cross-sectional data should cover the impact of the spatial structure of territories on the phenomena considered. This is because the level of a phenomenon in one unit can affect the level found in another unit. Hence, a process referred to as spatial autocorrelation can take place between neighbouring territories. For the purposes of spatial autocorrelation, a shared border is considered to be the proximity criterion. In practice this is the most common approach. Other criteria for the construction of the matrix are, for example, $k$ nearest neighbours, number of neighbours within a radius of $n$ kilometers, distance between areas, inverse distance between neighbours. In this method of modelling neighbourhoods, the starting point is a matrix consisting of binary values. A value of 1 means that the areas border each other, and 0 means that they do not.

The global Moran's $I$ was used in identifying spatial interactions between the values of defined metrics recorded in neighbouring districts (Kopczewska, 2007): 


$$
I=\frac{1}{\sum_{i=1}^{n} \sum_{j=1}^{n} w_{i j}} \cdot \frac{\sum_{i=1}^{n} \sum_{j=1}^{n} w_{i j}\left(x_{i}-\bar{x}\right)\left(x_{j}-\bar{x}\right)}{\frac{1}{n} \sum_{i=1}^{n}\left(x_{i}-\bar{x}\right)^{2}},
$$

where: $x_{i}, x_{j}$ : values observed in locations $i$ and $j(i, j=1,2, \ldots, n) ; \bar{x}$ : average value for all areas; $w_{i j}$ : entries of the spatial weight matrix.

An in-depth analysis can be carried out by calculating the local Moran's I:

$$
I_{i(w)}=\frac{\left(x_{i}-\bar{x}\right) \sum_{j=1}^{n} w_{i j}^{*}\left(x_{j}-\bar{x}\right)}{\sum_{i=1}^{n}\left(x_{i}-\bar{x}\right)^{2}} .
$$

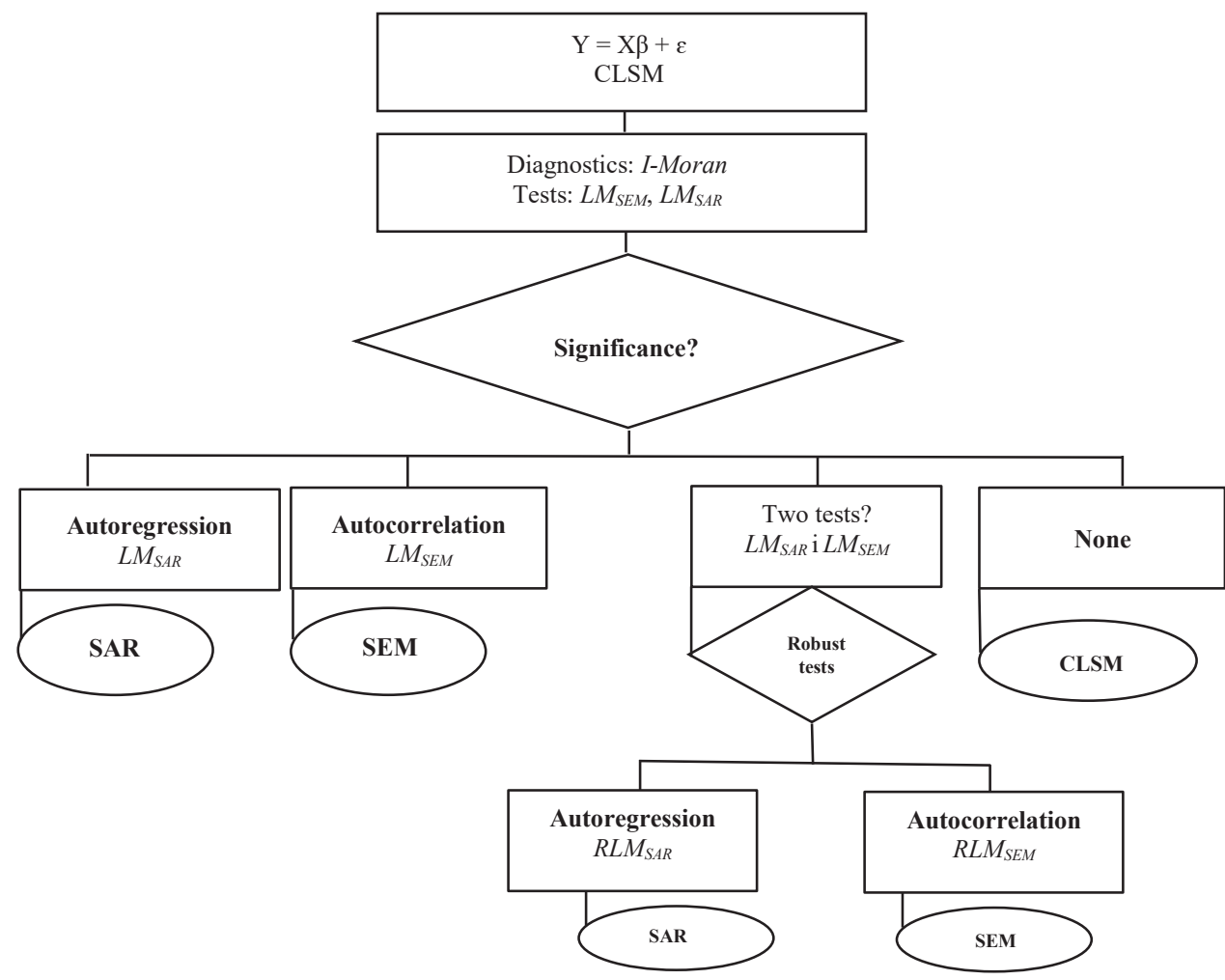

Fig. 1. Procedure for selecting the SAR/SEM spatial regression model variant.

Source: own study based on (Suchecki 2010, p. 302). 
A spatial regression analysis was carried out to assess the strength of spatial relationships between the synthetic indicators. The presence of spatial relationships contributes to changing the properties of structural parameters in models estimated with the least squares method. If spatial effects are identified, the spatial regression model is estimated in a manner to minimize their impact on the model's discriminatory capacity.

If spatial autocorrelation of residuals is detected, spatial estimation techniques must be applied. Two models' categories that identify that kind of spatial relations: SAR/SLM (spatial lag models) and SEM (spatial error models) may be distinguished.

The spatial lag model covers the so-called spatially lagged endogenous variable, which means that this is an autoregression model. Consecutively, the spatial error model includes the presence of spatial autocorrelation between residuals. The existence of spatial autocorrelation in the error term of the model may originate from the omission of non-observed variables which could be spatially correlated (Kopczewska, 2007).

The basic spatial lag models (SLM) may be expressed by the formula:

$$
y=\beta X+\rho W y+u, u \sim I I D N(0,1),
$$

where: $X$ - matrix of independent variables; $\beta$ - vector of coefficients; $W$ - matrix of spatial weights; $\rho$-spatial autocorrelation coefficient; $u$-model's error term; $W y$-spatial lag of dependent variable (understood as the level of dependent variable $y$ in neighbouring regions).

The basic spatial error models (SEM) may be expressed by the formula:

$$
y=\beta X+u, u=\lambda W u+\varepsilon, \quad \varepsilon \sim \operatorname{IID} N(0,1),
$$

where: $\lambda$ - spatial autocorrelation parameter; $W u$ - spatially lagged error term; $\varepsilon$-model's independent error term.

In spatial regression models, in addition to spatial interactions of forms of autoregression or autocorrelation of the random component, it is also worth analyzing the phenomenon of spatial heterogeneity, i.e. instability in the area of relations, e.g. of an economic nature. This may stem, among others from the phenomenon of the asymmetry of relations between the center and the periphery. Heteroskedasticity testing can be performed based on the Breusch-Pagan BP test:

$$
B P=\frac{1}{2}\left[g^{T} Z\left(Z^{T} Z\right)^{-1} Z^{T} g-N\right]^{a s} \sim \chi_{(k)}^{2},
$$

where: $g$ - vector formed basing on residuals of the model created with the CLS method; entries of the vector are: 


$$
g_{i}=\frac{e_{i}^{2}}{\left(\frac{e^{T} e}{N}\right)}
$$

$Z$ is the complete matrix of explanatory variables, $N$ is the total quantity of units (for instance, districts).

\section{Results}

The choice of variables was determined by the availability of complete, up-to-date data. The observations must demonstrate adequate variation (a non-diversified variable is of limited analytical value). The classic coefficient of variation was used to measure the diversification of variables. Variables with a coefficient of variation above $10 \%$ were retained for this study. Based on the above procedure, the following variables were eliminated from both sets: X19 and X27 (with a coefficient of variation of $4 \%$ and slightly above $6 \%$, respectively). A method referred to as the inverse correlation matrix was used to assess the information value. The inverse correlation matrix was calculated for each thematic sub-group of variables (in both sets). Following this, the variable corresponding to the highest diagonal entry of the inverse correlation matrix (above the critical threshold value fixed arbitrarily at $r^{*}=15$ ) was removed where needed. Next, the inverse correlation matrix was recalculated, and the diagonal entries were checked to see if they exceed the fixed threshold value. The above procedure resulted in eliminating P3. Of the variables referring to entrepreneurship levels, only $\mathrm{P} 4$ has an inhibiting effect (low values are desired). Other variables were classified as having a stimulating effect. When it comes to variables referring to the standard of living, X1, X5, X6 and X12 were found to have an inhibiting effect.

The table below presents the top 15 highest and top 15 lowest values of synthetic indicators of standard of living (SISL) and of entrepreneurship levels (SME). The ranking is based on the TOPSIS method.

Higher SISL values were usually recorded in urban districts. Peak levels were found in the capital cities of the Opolskie, Wielkopolskie and Dolnośląskie voivodeships. These territories recorded high levels of variables such as: usable floor area, number of doctors, hospital beds, and kindergarten pupils. Unemployment rates and the number of residents per pharmacy were low (which is desirable). In turn, 12 out of 15 districts with the lowest SISL values are located in the Dolnośląskie (5) and Zachodniopomorskie (7) voivodeships. The lowest values were identified in the Lwówecki, Górowski and Łobeski districts which also reported relatively low levels of the following variables: number of job opportunities, share of population served by treatment plants, and number of kindergarten pupils. On the other hand, they had a high unemployment rate. 
Table 1. Selected values of the synthetic indicator of standard of living and of entrepreneurship development levels

\begin{tabular}{|c|c|c|c|}
\hline District & SISL & District & SME \\
\hline city of Opole & 0.5898 & city of Poznań & 0.7235 \\
\hline city of Poznań & 0.5602 & city of Wrocław & 0.6848 \\
\hline city of Wrocław & 0.5540 & city of Opole & 0.5649 \\
\hline city of Leszno & 0.5291 & Wrocławski & 0.5361 \\
\hline city of Koszalin & 0.5111 & city of Szczecin & 0.5058 \\
\hline city of Zielona Góra & 0.5104 & Poznański & 0.5037 \\
\hline Kołobrzeski & 0.5090 & city of Zielona Góra & 0.4877 \\
\hline city of Gorzów Wlkp. & 0.5036 & Kołobrzeski & 0.4510 \\
\hline city of Kalisz & 0.5001 & city of Koszalin & 0.4333 \\
\hline Lubiński & 0.4992 & city of Jelenia Góra & 0.4232 \\
\hline city of Świnoujście & 0.4979 & Jeleniogórski & 0.4165 \\
\hline city of Szczecin & 0.4937 & city of Leszno & 0.4144 \\
\hline city of Jelenia Góra & 0.4897 & Policki & 0.4127 \\
\hline city of Legnica & 0.4838 & Kamieński & 0.4034 \\
\hline Kamieński & 0.4694 & Polkowicki & 0.3976 \\
\hline & & $\ldots$ & \\
\hline Pyrzycki & 0.4069 & Bolesławiecki & 0.2476 \\
\hline Wągrowiecki & 0.4068 & Chodzieski & 0.2457 \\
\hline Kamiennogórski & 0.4063 & Nowosolski & 0.2413 \\
\hline Szczecinecki & 0.4052 & Nyski & 0.2405 \\
\hline Ząbkowicki & 0.4040 & Kamiennogórski & 0.2383 \\
\hline Stargardzki & 0.4000 & Górowski & 0.2332 \\
\hline Namysłowski & 0.3997 & Międzyrzecki & 0.2312 \\
\hline Strzeliński & 0.3989 & Świdwiński & 0.2311 \\
\hline Świdwiński & 0.3983 & Kolski & 0.2188 \\
\hline Białogardzki & 0.3929 & Głogowski & 0.2182 \\
\hline Policki & 0.3922 & Czarnkowsko-Trzcianecki & 0.2157 \\
\hline Lwówecki & 0.3916 & Żagański & 0.2095 \\
\hline Górowski & 0.3857 & Złotowski & 0.2073 \\
\hline Łobeski & 0.3838 & Żarski & 0.2068 \\
\hline \multicolumn{4}{|c|}{ VARIATION $(\mathrm{N}=112)$} \\
\hline AVG & 0.4385 & AVG & 0.3210 \\
\hline $\mathrm{V}_{\mathrm{s}}$ & $8.3500 \%$ & $\mathrm{~V}_{\mathrm{s}}$ & $26.8008 \%$ \\
\hline SD & 0.0366 & $\mathrm{SD}$ & 0.0860 \\
\hline MED & 0.4293 & MED & 0.3083 \\
\hline Q1 & 0.4151 & Q1 & 0.2711 \\
\hline Q3 & 0.4508 & Q3 & 0.3392 \\
\hline
\end{tabular}

Source: own study. 
The three districts with the highest SISL values (the cities of Poznan, Wrocław and Opole) were also found to have the highest SME levels. These districts also reported high values of variables such as the number of operators entered to the REGON register, the number of commercial companies, and the share of recently $(<12$ months) registered operators active in the creative sector. In turn, the three districts with the lowest SME values had low levels of variables such as: number of natural persons engaged in an economic activity, number of recently registered foundations, and number of companies.

In $75 \%$ of districts, SISL was not in excess of 0.4508 , while SME did not go beyond 0.3392 . Both SISL and SME demonstrated right-side asymmetry (the classical skewness coefficient was 1.60 and 2.10 , respectively) which suggests the dominance of values equal to or below the mean. The results of the linear ordering routine are presented on maps with four naturally established classes.

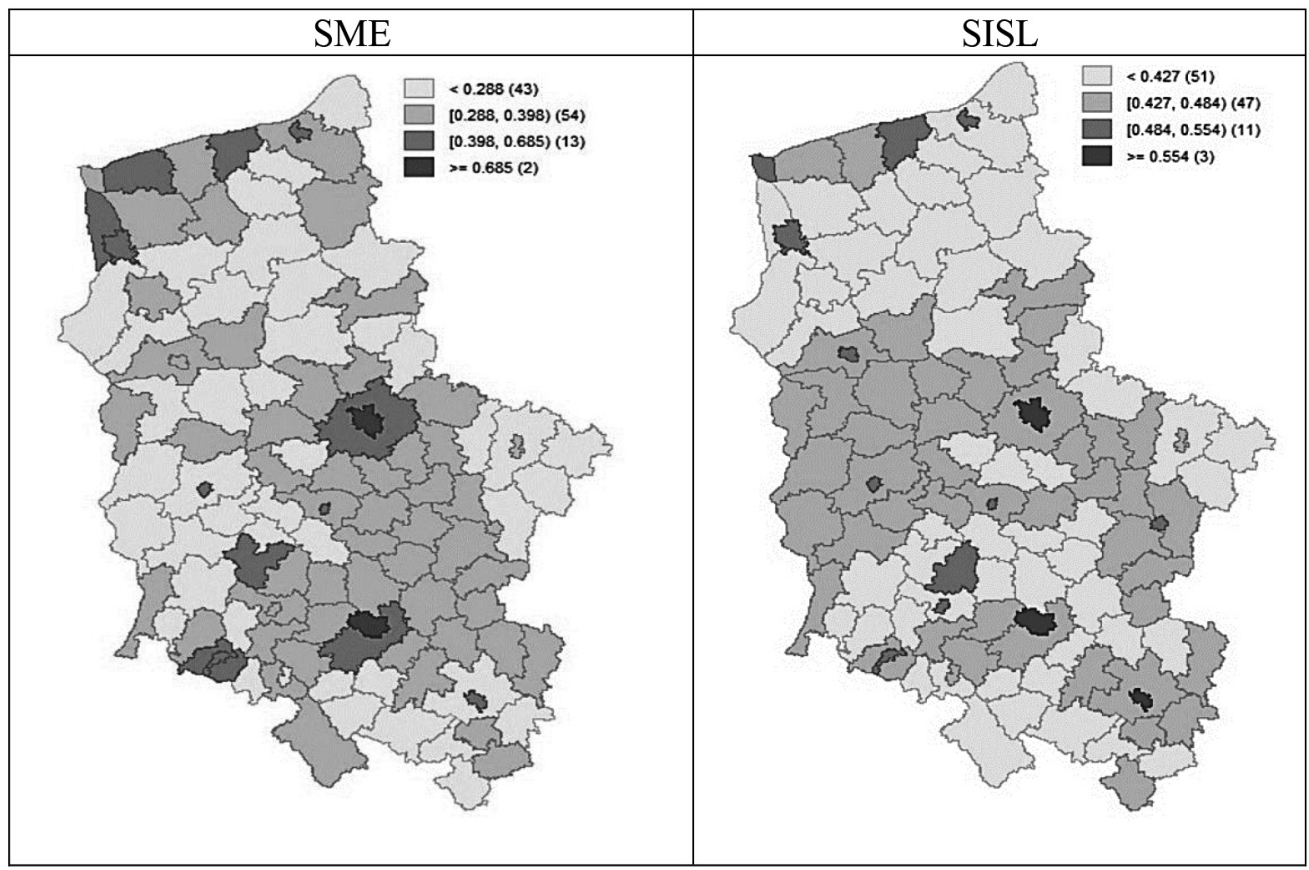

Fig. 2. Map of synthetic indicators of standard of living and of entrepreneurship levels.

Source: own study based on the Local Data Bank of the Central Statistical Office.

As shown by the calculations, a moderate correlation exists between the indicators. The Spearman rank correlation coefficient was 0.4624 , and was statistically significant at $\mathrm{p}<0.05$. 


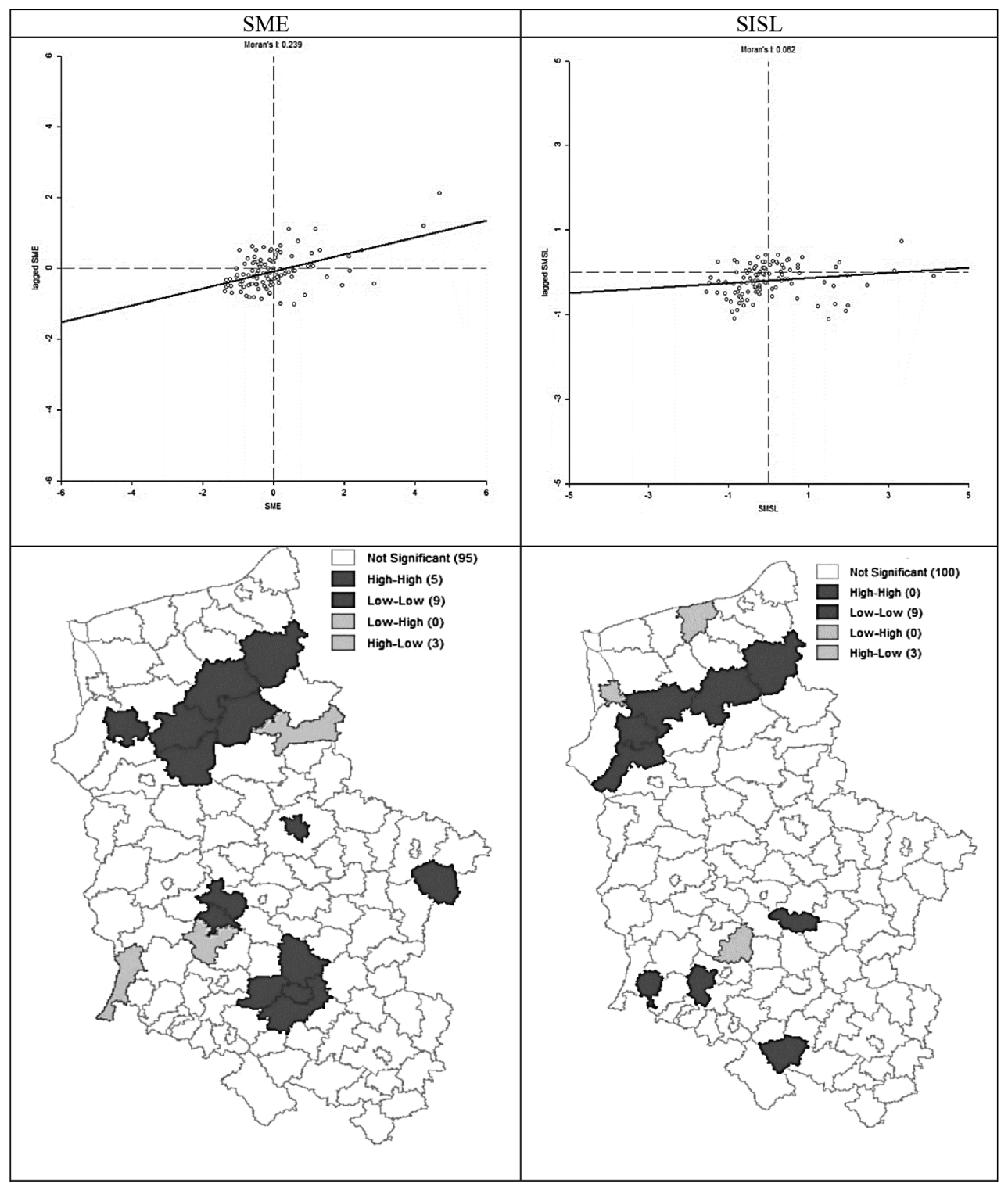

Fig. 3. Dot plot of the global statistic; map of selected local statistics Source: own study.

Obviously, each area (and each economic operator) is an integral part of the entire economy rather than an isolated element. Whatever happens in one unit can affect the processes taking place in another territorial unit. This is due to the fact that structural elements of individual territories (such as natural resources, infrastructure) form 
a specific set of interrelated components going beyond conventional administrative boundaries. Note also that the activity of residents (including commuting to work, school or cultural institutions) is of a cross-border nature, too. As a consequence, spatial autocorrelation may exist between the territories (defined as the correlation degree between the identified value of a variable in a specific location and the value of that variable in another location).

Global Moran's I statistics were calculated to estimate the strength and direction of the spatial relationship between the phenomena covered by this study. For SME, it was 0.2393 and was statistically significant at $\mathrm{p}<0.05$. In turn, for SISL, it was 0.0619 and was statistically significant at $p<0.1$. In the case of both SME and SISL, most points are located in the third quadrant of the dot plot for the global Moran's $I$ statistic. Hence, it may be assumed that districts are usually clustered by low values of synthetic indicators.

If only the global statistics are calculated, neither the areas with a locally stronger spatial relationship nor the outliers (associated with a locally negative spatial autocorrelation) can be identified, hence local statistics were used to circumvent this inconvenience. The table below presents statistically significant values of local Moran's $I_{i}$ statistics.

Table 2. Statistically significant values of local Moran's $I_{i}$ statistics

\begin{tabular}{|c|c|c|c|}
\hline District & $I_{i}$ & District & $I_{i}$ \\
\hline \multicolumn{4}{|c|}{ SME } \\
\hline Choszczeński & 0.8726 & Średzki ds & $0.4742 *$ \\
\hline Drawski & $0.4570^{*}$ & Trzebnicki & 0.5336 \\
\hline Głogowski & 0.5834 & Turecki & 0.5597 \\
\hline Pilski & -0.1855 & Wałecki & 0.5877 \\
\hline Polkowicki & -0.6617 & city of Wrocław & 5.0866 \\
\hline city of Poznań & 9.9356 & Wrocławski & 1.3091 \\
\hline Pyrzycki & 0.0674 & Wschowski & 0.2554 \\
\hline Strzel.-Drezd. & $0.2874 *$ & Zgorzelecki & $-0.5834^{*}$ \\
\hline Szczecinecki & 0.1092 & & \\
\hline \multicolumn{4}{|c|}{ SISL } \\
\hline Drawski* & $0.7053 *$ & Rawicki & 0.4292 \\
\hline Kołobrzeski* & $-1.7634 *$ & Stargardzki & 0.6711 \\
\hline Lubański & 0.3057 & city of Szczecin* & $-1.6773 *$ \\
\hline Lubiński & -1.2576 & Szczecinecki & $0.8481^{*}$ \\
\hline Myśliborski & 0.4213 & Ząbkowicki & 0.6549 \\
\hline Pyrzycki & $0.9478^{*}$ & Złotoryjski & 0.3546 \\
\hline
\end{tabular}

* Statistically significant at $\mathrm{p}<0.01$; other values are statistically significant at $\mathrm{p}<0.05$.

Source: own study. 
When analysing the local statistics for SME, it may be concluded that positive and statistically significant values were identified only in 14 districts (which means these districts are adjacent to territories with a similar value of that indicator), and statistically significant negative values of local statistics were identified in three districts. As regards other districts, local statistics for the variable considered were positive in 53 cases and negative in 42 cases which, however, were not statistically significant. When it comes to SISL, statistically significant local statistics were identified in 12 districts (nine positive and three negative). As regards other districts, local statistics were positive in 63 locations and negative (though not statistically significant) in 37 locations.

The values of local statistics enable identifying clusters of territories at similar levels of the phenomenon under consideration (Figure 3). Nine low-low areas (reporting low values of the variable) were identified for SME. These were: a large compact cluster of six districts in the Lubuskie and Zachodniopomorskie voivodeships (Strzelce - Drezdenecki, Szczecinecki, Pyrzycki, Wałecki, Choszczeński and Drawski districts); two neighboring districts located at the border of the Lubuskie and Dolnośląskie voivodeships (Wschowski and Głogowski districts), and the turecki district; also observed were 5 high-high areas (a high value of the indicator surrounded by high values). These were: the city of Poznań; four neighbouring districts comprising what is referred to as the Wrocław agglomeration, i.e. the city of Wrocław and the districts of Wrocław, Trzebnicki and Średzki. This study also

Table 3. Estimation results for the model of the standard of living: the classical model and the spatial error model

\begin{tabular}{|c|c|c|c|}
\hline \multicolumn{2}{|c|}{ Models } & Classical & SEM \\
\hline \multirow[t]{6}{*}{ Estimation } & $\lambda$ & - & $0,2472(0,0441)$ \\
\hline & Intercept & $0.3446(0.0000)$ & $0.3409(0,0000)$ \\
\hline & SME & $0.2925(0.0000)$ & $0.3091(0,0000)$ \\
\hline & AIC & -491.6420 & -495.1840 \\
\hline & $\mathrm{SC}$ & -486.2050 & -489.7470 \\
\hline & Log likelihood & 247.8210 & 249.5921 \\
\hline \multicolumn{4}{|c|}{ Normality test } \\
\hline JB & & $3.5049(0.1734)$ & - \\
\hline \multicolumn{4}{|c|}{ Heteroscedasticity test } \\
\hline BP & & $0.1091(0.7411)$ & $0.0962(0.7564)$ \\
\hline \multicolumn{4}{|c|}{ Spatial autocorrelation tests } \\
\hline Moran $I_{\text {error }}$ & & $2.0719(0.0383)$ & - \\
\hline $\mathrm{RLM}_{\mathrm{SAR}}$ & & $4.0042(0.0454)$ & - \\
\hline $\mathrm{RLM}_{\mathrm{SEM}}$ & & $7.0855(0.0078)$ & - \\
\hline
\end{tabular}

Source: own calculations. 
identified three high-low areas (a high value of the indicator surrounded by low values): the districts of Piła, Polkowice and Zgorzelec. When it comes to SISL, this study identified nine low-low areas (primarily including the cluster of five districts located in the Zachodniopomorskie voivodeship: Szczecinecki, Stargadzki, Pyrzowicki, Drawski and Myśliborski); also observed were three high-low areas (Lubiński, Kołobrzeski and the city of Szczecin).

The spatial regression analysis was carried out next. The classical least squares method was used to estimate the structural parameters of the linear regression model in the first step of this study. The results of the Jarque-Bera test did not allow for the hypothesis of normal distribution of the random effect being rejected. Therefore, the values of asymptotic Lagrange multiplier tests can be calculated, and the maximum likelihood method can also be used. This is important because if spatial autocorrelation exists, the estimator based on the classical least squares method can be incompatible (or at least inefficient) with spatial error models, for instance.

As shown by the calculations, spatial autocorrelation exists between residuals, therefore spatial estimation methods need to be used in the model. Two groups of models exist that take such spatial relationships into account: SAR, referred to as spatial lag models (SLM), and SEM (spatial error models).

Robust Lagrange multiplier tests were used to determine the type of spatial interaction: $\mathrm{RLM}_{\mathrm{SEM}}$ (for the autocorrelation of the random effect) and $\mathrm{RLM}_{\mathrm{SAR}}$ (for the autoregression of the explained variable):

$$
\begin{gathered}
R L M_{S E M}=\left(\frac{1-T_{2} T_{1}}{T_{1}}\left(\frac{\boldsymbol{e}^{T} \boldsymbol{W y}}{\hat{\sigma}^{2}}-\frac{T_{1}}{T_{2}} \frac{\boldsymbol{e}^{T} \boldsymbol{W e}}{\hat{\sigma}^{2}}\right)^{2}\right) \stackrel{a s}{\sim} \chi_{(1)}^{2}, \\
R L M_{S A R}=\left(\frac{1}{T_{2}-T_{1}}\left(\frac{\boldsymbol{e}^{T} \boldsymbol{W} \boldsymbol{y}}{\hat{\sigma}^{2}}-\frac{\boldsymbol{e}^{T} \boldsymbol{W e}}{\hat{\sigma}^{2}}\right)^{2}\right) \stackrel{a s}{\sim} \chi_{(1)}^{2} .
\end{gathered}
$$

The comparison of test values (calculated ex ante based on the residuals of the model estimated with the least squares method) decided the use of the spatial lag model $^{1}\left(\mathrm{RLM}_{\mathrm{SEM}}>\mathrm{RLM}_{\mathrm{SAR}}\right)$. In its structural form, the estimated model may be written as:

$$
\begin{gathered}
\text { SISL }=0.3409+0.3091 \cdot S M E+u, \\
u=0.2472 \cdot W_{u}+\varepsilon .
\end{gathered}
$$

All regression coefficients are statistically significant. This means the variables included in the model have an effect on SISL. Since $\lambda$ is statistically significant, it can be assumed that spatially autocorrelated factors exist outside the model that

${ }^{1}$ Form of the estimated SAR model: SISL $=0.2901 \cdot \mathrm{SME}+0.1021 \cdot W$ SISL +0.3013 , where the autoregression parameter was not statistically significant $(0.1021, p$-value $=0.3667)$. Other model parameters were statistically significant at the significance level $p<0.05$. 
affect the standards of living in districts of West Poland. This means that the model fails to take account of some non-observed (e.g. random) variables which can be spatially correlated.

Due to the presence of a spatial dependency of errors, the exogenous shock in a given territorial unit within the spatial error model will affect not only the situation prevailing in that very unit but also the condition of neighbouring units (Kopczewska, 2007). The estimated parameters of the spatial error model give grounds for concluding that a 1 unit increase in the value of the synthetic indicator of entrepreneurship results, ceteris paribus, in a nearly 0.31 increase in the synthetic indicator of the standards of living in the territorial units considered. The model which includes the mean error in neighbouring locations may be concluded to be better than the one based on classical least squares, according to the Akaike and Schwarz information criteria. Similar conclusions may be drawn based on the log-likelihood ratio.

The results of the Breusch-Pagan test $(B P=0.0962, p$-value $=0.7564)$ did not allow for the rejection of the null hypothesis about the homoscedasticity of the random component $(p>0.05)$. The constructed spatial regression model could be used for analysis, without the need to introduce expanding variables (reflecting the variability of parameters, e.g. east-west type, centre-periphery).

\section{Conclusion}

The development of entrepreneurship contributes to improving the economic situation at local and regional level. The level of entrepreneurship in different units has an effect not only on economic operators but also on many existential factors faced by the entire population. Therefore, measures taken by local authorities in charge of promoting entrepreneurship (including attracting more investment, offering certain tax reliefs) take on particular importance.

This paper examined the relationships between standard of living and the levels of entrepreneurship expressed with synthetic variables. According to this study (which relied on 2018 data), a positive correlation exists between the TOPSIS-based synthetic indicators (the Spearman rank correlation coefficient was 0.46). Moreover, positive spatial autocorrelation was discovered for each of the indicators. The results of the regression analysis give grounds for concluding that a 1 unit increase in the value of the synthetic indicator of entrepreneurship level results in a nearly 0.31 increase in the synthetic indicator of standard of living in districts of West Poland (under the assumption that other factors remain constant).

The findings from research on spatial structures which focus on the standards of living and their determinants can either directly or indirectly promote the initiation of relevant measures (e.g. taken by local authorities at different levels to design entrepreneurship development programs). They may also become the basis for the appropriate adjustments to strategic actions taken to stimulate local socioeconomic 
development and thus to achieve the highest possible standard of living. This is related to the fact that the level of phenomena covered by this analysis may determine, and be determined by, the corresponding levels recorded in other locations. Further research could analyse a neighbourhood of an order higher than one, or another spatial structure of neighbourhood (e.g. the Bishop pattern). Alternatively, another level of data aggregation could be used. It would also be useful to carry out research at international level, although access to unified statistical data would be a considerable challenge. It is also worth conducting causality tests (e.g. the Granger test) between individual partial variables. Conducting causality tests would not only confirm the existence of a relation between variables and determine its nature, but most importantly allow to determine the direction of this relation. This is of significance due to the fact that there may be an inverse relation between the analysed categories, which was not the subject of the analysis.

\section{References}

Bank Danych Lokalnych GUS. (n.d.). Retrieved from https://bdl.stat.gov.pl/BDL/start

Bellingham, L. (ed.). (2012). Enterprise and entrepreneurship education: Guidance for UK higher education providers. Gloucester: The Quality Assurance Agency for Higher Education.

Berbeka, J. (2006). Poziom życia ludności a wzrost gospodarczy w krajach Unii Europejskiej. Kraków: Wydawnictwo Akademii Ekonomicznej w Krakowie.

Bywalec, C., and Rudnicki, L. (1992). Podstawy teorii i metodyki badania konsumpcji, Kraków: Akadamia Ekonomiczna w Krakowie.

Hansen, M. E., and Grubb, F. (2002). Anthropometric versus income measures of the standard of living: issues of theoretical consistency. Retrieved from http://www.humanics-es.com/anthro11-13-02.pdf

Hwang, C. L. and Yoon, K. (1981). Multiple attribute decision making: methods and applications. Berlin-Heidelberg-New York: Springer-Verlag.

Janusz, M. (2014). Poziom życia i jego przestrzenne zróżnicowanie w województwie warmińsko-mazurskim. Ekonomia i Zarzadzanie, 4, 169-184.

Karwowski, J. (2003). Jakość życia w regionie. Szczecin: Wydawnictwo Naukowe Uniwersytetu Szczecińskiego.

Klasik, A. (2006). Przedsiębiorczość i konkurencyjność a rozwój regionalny. Katowice: Wydawnictwo Akademii Ekonomicznej w Katowicach.

Kopczewska, K. (2007). Ekonometria i statystyka przestrzenna z wykorzystaniem programu R-Cran. Warszawa: CeDeWu.

Kotowska, I. E., Matysiak, A., Styrc M., Pailhe, A., Solaz, A., and Vignoli, D. (2010). Drugie europejskie badanie jakości życia. Życie rodzinne i praca. Luksemburg: Eurofound.

Kotowski, J., and Pięta, S. (2018). Przedsiębiorstwa niefinansowe powstałe w 2017 r. Warszawa: GUS.

Kuciński, K. (1997). Przestrzenne aspekty przedsiębiorczości. Warszawa: Oficyna Wydawnicza SGH.

Kwasek, M. (2002). Poziom życia rolników w ostatniej dekadzie XX wieku. Warszawa: IERiGŻ.

Liang, Z., Changdi, S. and Liming, L. (2017). Application of the AHP Method and the TOPSIS Method in Comprehensive Economic Strength Evaluation of Major Cities in Guizhou Province (International Conference on Computer Science and Application Engineering, CSAE 2017). Shanghai.

Młodak, A. (2006). Analiza taksonomiczna w statystyce regionalnej. Warszawa: Difin.

Mourad, M., Perez, A., and Richardson, C. (2014). Digital Inclusion Social Impact Evaluation. Final Report. Washington: One Global Economy. 
Mularska-Kucharek, M. (2016). Przedsiębiorczość a jakość życia. Zarządzanie Zasobami Ludzkimi, (1), 141-153.

Piecuch, T. (2010). Przedsiębiorczość. Podstawy teoretyczne. Warszawa: C.H. Beck.

Słaby, T. (2007). Poziom i jakość życia. In Panek T. (ed.), Statystyka społeczna. Warszawa: PWE.

Suchecki, B. (2010). Ekonometria przestrzenna. Metody i modele analizy danych przestrzennych. Warszawa: Wydawnictwo C.H. Beck.

Sudoł, S. (2006). Przedsiębiorstwo. Podstawy nauki o przedsiębiorstwie. Zarzadzanie przedsiębiorstwem. Warszawa: Polskie Wydawnictwo Ekonomiczne.

Szczygieł, E., and Piecuch, T. (2016). Rozkłady dochodów przedsiębiorców i ich użyteczność na tle innych grup społeczno-ekonomicznych. Nierówności Społeczne a Wzrost Gospodarczy, 48(4), 116-128.

Szot-Gabryś, T. (2008). Znaczenie przedsiębiorczości i innowacji dla rozwoju regionu, In. Pałaszewska-Reindl T., Szot-Gabryś T. (eds.), Uwarunkowania rozwoju przedsiębiorczości i innowacji, Kielce: WSU im. S. Staszica w Kielcach.

Śleszyński, P. (2007). Gospodarcze funkcje kontrolne w przestrzeni Polski. Warszawa: PAN IGiPZ.

Świętek, A. (2018). Poziom przedsiębiorczości w krajach europejskich w świetle wskaźników TEA i EEA a występujące w wybranych z nich modele kształcenia przedsiębiorczości. Przedsiębiorczość - Edukacja, (14), 445-459.

Tarnawa, A., Węcławska, D., Nieć, M., and Zbierowski P. (2017). Raport z badania Global Entrepreneurship Monitor - Polska. Warszawa: PARP.

Tarnawa, A., and Zadura-Lichota P. (2015). Raport o stanie sektora matych $i$ średnich przedsiębiorstw $w$ Polsce w latach 2013-2014. Warszawa: PARP.

Zeliaś, A. (2004). Poziom życia w Polsce i krajach Unii Europejskiej. Warszawa: PWE.

\section{PRZEDSIĘBIORCZOŚĆ A POZIOM ŻYCIA MIESZKAŃCÓW W POLSCE ZACHODNIEJ - ANALIZA PRZESTRZENNA}

Streszczenie: Zamiarem autora artykułu było przedstawienie zależności między poziomem rozwoju przedsiębiorczości a poziomem życia mieszkańców. Badaniami objęto 112 powiatów w województwach dolnośląskim, lubuskim, opolskim, wielkopolskim i zachodniopomorskim. Do oceny poziomu przedsiębiorczości i poziomu życia wykorzystano metodę TOPSIS. Dobór zmiennych został dokonany na podstawie kryteriów merytorycznych, statystycznych i formalnych (głównie kompletność i dostępność danych dla badanych obiektów w 2018 r.). Z badań wynika, że między analizowanymi zjawiskami zachodzi umiarkowana zależność korelacyjna. Na podstawie wyników analizy regresji przestrzennej można stwierdzić, że wzrost wartości syntetycznego miernika poziomu przedsiębiorczości o 1 jednostoskę powoduje wzrost wartości syntetycznego miernika poziomu życia w poszczególnych powiatach o 0,31 , przy założeniu ceteris paribus.

Słowa kluczowe: poziom życia, porządkowanie liniowe, regresja przestrzenna. 